\title{
Pengaruh Current Ratio, Debt Equity Ratio, Total Assets Turn Over Dan Net Profit Margin Terhadap Pertumbuhan Laba
}

\author{
Shinta Estininghadi \\ STIE PGRI Dewantara Jombang \\ *Korespondensi: shinta22@gmail.com
}

\begin{abstract}
Abstrak
Pertumbuhan laba adalah peningkatan dan penurunan laba yang diperoleh perusahaan dibandingkan dengan periode atau tahun sebelumnya, Penelitian ini bertujuan untuk mengetahui dan menganalisis pengaruh Current Ratio, Debt to Equity Ratio, Total Assets Turnover, Net Profit Margin terhadap pertumbuhan laba. Metode penelitian ini menggunakan metode kuantitatif. Metode pengumpulan data menggunakan data sekunder. Teknik sampel menerapkan nonprobability sampling dan sampel jenuh. Populasi dalam penelitian ini sejumlah 33 laporan keuangan perusahaan sektor Property and Real Estate pada tahun 2017 yang terdaftar di Bursa Efek Indonesia. Berdasarkan penelitian ini menunjukkan bahwa secara parsial variabel yang berpengaruh terhadap pertumbuhan laba adalah Debt to Equity Ratio dan Total Assets Turnover, sedangkan variabel yang tidak berpengaruh terhadap pertumbuhan laba adalah Current Ratio dan Net Profit Margin.
\end{abstract}

Kata kunci: Current Ratio, Debt to Equity Ratio, Total Assets Turnover, Net Profit Margin, Pertumbuhan Laba.

\begin{abstract}
Profit growth is an increase and decrease in profits earned by the company compared to the previous period or year, This study aims to determine and analyze the influence of Current Ratio, Debt to Equity Ratio, Total Assets Turnover, Net Profit Margin on profit growth. This research method uses quantitative methods. The method of collecting data uses secondary data. The sample technique applies nonprobability sampling and saturated samples. The population in this study numbered 33 financial statements of the Property and Real Estate sector in 2017 which were listed on the Indonesia Stock Exchange. Based on this study shows that partially the variables that influence earnings growth are Debt to Equity Ratio and Total Assets Turnover, while variables that do not influence earnings growth are the Current Ratio and Net Profit Margin.

Keywords: Current Ratio, Debt to Equity Ratio, Total Assets Turnover, Net Profit Margin, Profit Growth
\end{abstract}

\section{A. Pendahuluan}

Dalam dunia bisnis tidak akan berjalan sesuai dengan apa yang kita harapkan atau wujudkan. Bisnis akan selalu ada titik permasalahan, dimana ekonomi itu bisa mengalami sebuah kerugian ataupun keuntungan. Didalam perusahaan selalu ada seorang manajer yang harus mampu mengambil langkah atau strategi yang tepat untuk mengambil keputusan dengan itu perlu adanya mencari dan mengumpulkan informasi agar dalam pengambilan keputusannya dapat menghasilkan yang terbaik. Informasi yang didapat untuk mengambil keputusan ialah sebuah laporan keuangan perusahaan.

Laporan keuangan adalah sebagai alat untuk memperoleh informasi atau mengenai posisi keuangan dan hasil yang diperoleh dari perusahaan. Dari laporan keuangan perusahaan dapat diketahui informasi tentang kinerja perusahaan, aliran kas dan informasi lain yang berkaitan dengan laporan keuangan. Oleh karena itu, laporan keuangan dapat digunakan dalam kebijakan pengambilan keputusan.

Analisis rasio merupakan interpretasi atau proses informasi keuangan untuk menjelaskan hubungan terttentu antara angka yang satu dengan angka yang lain dari laporran keuangan. Dengan analisis rasio dapat kita peroleh antara kekuatan dan kelemahan perusahaan dibidang 
keuangan. Seorang investor dapat membuat keputusan atau pertimbangan untuk mewujudkan harapan perusahaan yaitu laba yang maksimal dengan menggunakan analisis rasio.

Pengertian laba menurut Harahap (2010:263), angka yang pentiing dalam laporan keuangan karena sebagai alasan yaitu laba merupakan dasar dalaam perhitungan pajak, pedoman dalam menentukan kebijakan investasi dan pengambilan keputusan, dasar dalam peraamalan laba maupun kejadiian ekonomi perusahaan lainnya dimasa yang akaan datang, dasar dalam perhitungan penilaian prestasi atau kinerja. Secara akuntansi, selisih pendapatan dan pengeluaran atau biaya adalah definisi laba .

Pertumbuhan laba adalah peningkatan dan penurunan laba yang diperoleeh perusahaan dibandingkan dengan periode atau tahun sebelumnya, Perusahaan pasti menginginkan adanyaa peningkatan laba yaang diperoleh dalam setiap tahunnya. Peningkatan dan penurrunan laba dilihat dari pertumbuhan laba setiap periode sebelumya dan masa yang akan datang. Informasi pertumbuhan laba sangat penting bagi pebisnis, seorang analis keuangan, pemegang saham, ekonom, dan sebagainya.

Rasio ini merupakan alat atau cara analisis yang daapat memberikan jalan keluar dan menggambarkan gejala-gejala yaang tampak oleh suatu keadaan didalam perusahaan. Rasio juga dapat menunjukkan bagian mana yang perlu untuk diteliti dan penanganan yang lebih mendalam. Secara umum, rasio keuangan dapat dikelompokkan menjadi empat rasio yaitu terdiri dari rasio likuiditas, rasio solvabilitas, rasio aktivitas dan rasio profitabilitas. Dalam penelitian ini, peneliti hanya membatasi beberapa faktor yang akan diteliti yang diduga berpengaruh terhadap pertumbuhan laba di antaranya Current Ratio (CR), Debt Equity Ratio (DER), Total Asset Turn Over Ratio (TATO) dan Net Profit Margin (NPM).

Rumusan masalah dalam penelitia ini Apakah Current Ratio (CR), Debt Equity Ratio (DER), Total Asset Turn Over Ratio (TATO) dan Net Profit Margin (NPM) berpengaruh signifikan terhadap pertumbuhan laba? Tujuan penelitian ini untuk mengetahui dan mejelaskan pengaruh Current Ratio (CR), Debt Equity Ratio (DER), Total Asset Turn Over Ratio (TATO) dan Net Profit Margin (NPM) berpengaruh signifikan terhadap pertumbuhan laba.

\section{B. Landasan Teoritis}

1. Laporan keuangan

Menurut Fahmi (2012:21), laporan keuangan merupaakan suatu informasi yang menggambarkan kondisi keuangan suaatu perusahaan, dan lebih jauh informasi tersebut dapat diijadikan sebagai gambaran kinerja keuangan perusahaan tersebut. Laporan keuangan digunakan untuk mengetahui perkembangan suatu perusahaan dan kondisi keuangan perusahaan.

2. Jenis laporan keuangan

Perusahaan diharuskan untuk menyusun beberapa jenis laporan keuangan yang sesuai dengan standar yang telah ditentukan, terutamaa untuk kepentingan pihak lain. Jenis laporan keuangan menurut (Kasmir, 2015) terdiri dari empat yaitu neraca, laporan laba rugi, laporan catatan atau laporan keuangan, dan laporan perubahan modal.

3. Analisis laporan keuangan

Analisis laporan keuangan suatu perusahaan pada dasarnya dilakukan untuk melihat prospek dan resiko perusahaan. Prospek tersebut adalah untuk mengetahui tingkat keuntungan (profitabilitas) sedangkan resiko untuk mengetahui perusahaan tersebut sedang mengalami kesulitan keuangan atau tidak.

4. Analisis rasio keuangan

Definisi rasio keuangan ini merupakan kegiatan yang membandingkan angka-angka yang ada didalam laporan keuangan deengan cara membagi satu angka deengan angka lainnya 
(Kasmir, 2012:104). Rasio keuangan terdiri dari empat yaitu rasio likuiditas, solvabilitas, aktivitas, dan profitabilitas.

5. Pertumbuhan laba

Pertumbuhan laba merupakan peningkatan dan penurunan laba yaang diperoleh perusahaan dibandiingkan dengan tahun sebelumnya. Besar dan kecilnya laba sebagai pengukur kennaikan aktiva sangat tergantung pada ketepatan pengukuran pendapatan dan biaya.

\section{Kerangka Konseptual}

Pada penelitian ini, rasio keuangan yang digunakan yaitu: Current Ratio (CR), Debt to Equity Ratio (DER), Total Assets Turn Over (TATO) dan Net Profit Margin (NPM). CR Rasio ini menunjukan rasio untuk meengukur kemampuan perusahaan dalaam membayar kewajiiban jangkaa pendek atau utang yang segeera jatuh tempo pada saat ditagih secaraa keseluruhan (Sugiyono, 2011:64). DER menggambarkan rasio yang dapat digunakan untuk menilai utang jangkapanjang dengan modal sendiri (Sugiyono, 2011:64). TATO berfungsi untuk rasio yang digunakaan untuk mengukur perputaran semua aktiva yang diimiliki perusahaan dan meengukur berapa jumlah penjualan yang diperoleeh dari tiap rupiah aktiva (Sugiyono, 2011:64). NPM menunjukkan perbandingan antaara laba bersih setelah pajak (NIAT) teerhadap total penjualannya (Sugiyono, 2011:64). Hal-hal diatas dapat berpengaruh terhadap besarnya laba yang akan diperoleh perusahaan. Berdasarkan uraian diatas dapat digambarkan kerangka konseptual sebagai berikut:

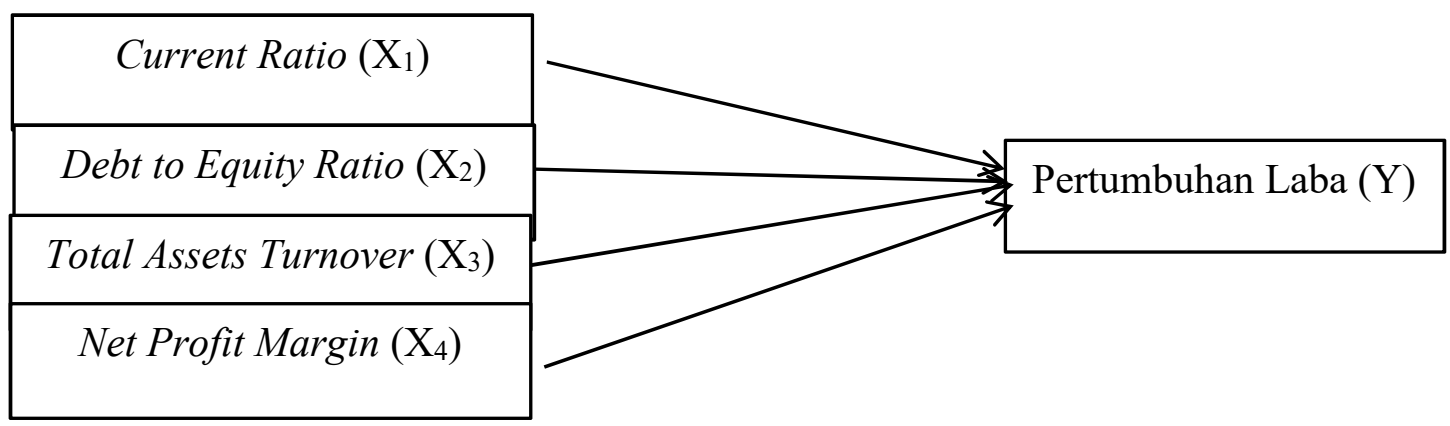

\section{Hipotesis}

\section{Gambar 1. Kerangka Konseptual}

Berdasarkan latar belakang, landasan teori dan penelitian terdahulu maka hipotesis penelitian ini adalah :

$\mathrm{H}_{1} \quad$ : $C R$ berpengaruh terhadap pertumbuhan laba.

$\mathrm{H}_{2} \quad$ : DER berpengaruh terhadap pertumbuhan laba.

$\mathrm{H}_{3} \quad$ : TATO berpengaruh terhadap pertumbuhan laba.

$\mathrm{H}_{4} \quad: N P M$ berpengaruh terhadap pertumbuhan laba.

\section{Metode Penelitian}

Penelitian ini menggunakan populasi berupa perusahaan-perusahaan properti yang terdaftar di Bursa Efek Indonesia yang tergolong dalam perusahaan manufaktur. Pemilihan sampel ditentukan secara nonprobability sampling dan menggunakan sampling jenuh karena sensus dimana semua anggota populasi dijadikan sebagai sampel diperoleh 33 data sampel. Data dalam penelitian ini menggunakan teknik dokumentasi yaitu dengan pengumpulan data dengan cara mengumpulkan data sekunder dari laporan keuangan yang telah dipublikasikan di BEI dan laporan tahunan 2017. 


\section{Hasil dan Pembahasan}

\section{Statistik Deskriptif}

Analisis statistic deskriptif digunakan untuk memberikan gambaran atau deskriptif suatu data tersebut disajikan dari nilai rata-rata, standar deviasi, varian, minimum dan maximum dari masing-masing variabel penelitian. . Berikut adalah uji statistik deskriptif pada masing-masing variabel:

Tabel 1. Hasil Analisis Statistik Deskriptif

\begin{tabular}{|c|c|c|c|c|c|}
\hline & $\mathrm{N}$ & Minimum & Maximum & Mean & $\begin{array}{c}\text { Std. } \\
\text { Deviation }\end{array}$ \\
\hline Current Ratio & 33 & .01 & 7.19 & 4.0461 & 2.15526 \\
\hline Debt to Equity Ratio & 33 & .02 & 2.83 & .3961 & .35372 \\
\hline $\begin{array}{l}\text { Total Assets } \\
\text { Turnover }\end{array}$ & 33 & .07 & 2.86 & .3656 & .35841 \\
\hline Net Profit Margin & 33 & .01 & 3.96 & .3282 & .61425 \\
\hline Pertumbuhan Laba & 33 & .00 & 6.27 & .5685 & .88402 \\
\hline Valid N (listwise) & 33 & & & & \\
\hline
\end{tabular}

Sumber : lampiran SPSS, 2018

Variabel Current Ratio menunjukan nilai maksimum sebesar 7,19 dan nilai minimum sebesar 0,01. Nilai rata-rata (mean) pada variabel Current Ratio sebesar 4,0461 lebih besar dari standaar deviasi yaitu 2.155. Variabel Debt to Equity Ratio menunjukan nilai maksimum sebesar 2,83 dan nilaai minimum sebesar 0,02. Nilai rata-rata (mean) pada variabel Debt to Equity Ratio sebesar 0.3961 lebih besar dari standar deviasi sebesar 0,3537. Variabel Total Assets Turnover meenunjukan nilai maksimum sebesar 2.86 dan nilai minimum sebesar 0,07. Nilai rata-rata (mean) pada variabel Total Assets Turnover sebesar 0,3656 lebih besaar dari standar deviasi yaitu 0,3584 yang artinya data Total Assets Turnover tersebut stabil, merata dan tidak terjadi penyimpangan. Variabel Net Profit Margin menunjukan nilaai maksimum sebesar 3.96 dan nilai minimum sebesar 0,01. Nilai rata-rata (mean) pada variabel Net Profit Margin sebesar 0,3282 lebih kecil dari standar deeviasi yaitu 0,6142. Variabel Pertumbuhan Laba menunjukan nilaai maksimum sebesar 6.27 dan nilai minimum sebesar 0,00. Nilai rata-rata (mean) pada variabel Net Profit Margin sebesar 0,5685 lebih kecil dari standar deviasi yaitu 0,8840 .

\section{Uji Normalitas}

Ada dua cara untuk mendeteksi apakah residual terdistribusi normal atau tidak yakni dengaan analisis grafik dan uji statistiik untuk menguji data apakah terdistriibusi normal atau tidak dengan menggunakan uji statistik Kolmogrov-Smirnov Test jika residual memiliki nilai signifikasi > 0,05 maka data terdistriibusi normal (Ghozali, 2011: 160). 
Tabel 2. Hasil Analisis Uji Normalitas

One-Sample Kolmogorov-Smirnov Test

\begin{tabular}{|c|c|c|c|c|c|c|}
\hline & & $\begin{array}{l}\text { Current } \\
\text { Ratio }\end{array}$ & $\begin{array}{c}\text { Debt to } \\
\text { Equity } \\
\text { Ratio }\end{array}$ & $\begin{array}{l}\text { Total Assets } \\
\text { Turnover }\end{array}$ & $\begin{array}{c}\text { Net } \\
\text { Profit } \\
\text { Margin }\end{array}$ & $\begin{array}{c}\text { Pertumb } \\
\text { uhan } \\
\text { Laba }\end{array}$ \\
\hline \multicolumn{2}{|l|}{$\mathrm{N}$} & 33 & 33 & 33 & 33 & 33 \\
\hline \multirow{2}{*}{$\begin{array}{l}\text { Normal } \\
\text { Parameters }^{\mathrm{a}}\end{array}$} & Mean & 2.3197 & .4631 & .4491 & .5168 & .8070 \\
\hline & $\begin{array}{l}\text { Std. } \\
\text { Deviation }\end{array}$ & 1.81338 & .49487 & .49654 & .83251 & 1.21247 \\
\hline \multirow{3}{*}{$\begin{array}{l}\text { Most } \\
\text { Extreme } \\
\text { Differences }\end{array}$} & Absolute & .168 & .184 & .241 & .357 & .254 \\
\hline & Positive & .168 & .180 & .241 & .357 & .252 \\
\hline & Negative & -.132 & -.184 & -.224 & -.270 & -.254 \\
\hline \multicolumn{2}{|c|}{ Kolmogorov-Smirnov Z } & .963 & 1.059 & 1.382 & 2.050 & 1.459 \\
\hline \multicolumn{2}{|c|}{ Asymp. Sig. (2-tailed) } & .312 & .212 & .054 & .100 & .128 \\
\hline
\end{tabular}

a. Test distribution is

Normal.

Sumber : lampiran SPSS, 2018

Berdasarkan tabel 2 di atas, dapat kita lihat bahwa nilai sig. dari keempat variabel mendeskripsikan nilai-nilai dari seemua variabel penelitian, yaitu : Current Ratio, Debt to Equity Ratio, Total Assets Turnover, Net Profit Margin lebih dari 0,05. Maka daapat disimpulkan bahwa pada keempat variabel yakni Current Ratio, Debt to Equity Ratio, Total Assets Turnover, Net Profit Margin berdiistribusi normal.

\section{Uji Multikolineritas}

Adanya Multikolinearitas dapaat dilihat dari tolerance value atau nilai variance inflation faactor (VIF). Jika nilaai Variance Inflation Factor (VIF) tidak lebih dari 10 dan nilai tolerance dibaawah 1 maka model terbebas dari multikolinearitas. Berikut ditunjukkan hasil uji dengan menggunakan SPSS 20.

Tabel 3. Uji Multikolinieritas

\begin{tabular}{|c|c|c|c|}
\hline \multicolumn{4}{|c|}{ Coefficients $^{\mathbf{a}}$} \\
\hline \multirow[b]{2}{*}{ Model } & & \multicolumn{2}{|c|}{ Collinearity Statistics } \\
\hline & & Tolerance & VIF \\
\hline \multirow[t]{5}{*}{1} & (Constant) & & \\
\hline & Current Ratio & .881 & 1.135 \\
\hline & Debt to Equity Ratio & .670 & 4.907 \\
\hline & Total Assets Turnover & .670 & 4.886 \\
\hline & Net Profit Margin & .991 & 1.009 \\
\hline
\end{tabular}

a. Dependent Variable: Pertumbuhan Laba

Sumber : lampiran SPSS, 2018

Berdasarkan tabel di atas, dapaat kita lihat bahwa nilai tolerance dan VIF dari keempat variabel mendeeskripsikan nilai-nilai dari semua variabel penelitian, yaitu : Current Ratio, Debt to Equity Ratio, Total Assets Turnover, Net Profit Margin tidak leebih dari 10 dan niilai Tolerance kedua variabel diatas 0,1. Maka dapat disimpulkan bahwa pada keempat variabeel 
yakni Current Ratio, Debt to Equity Ratio, Total Assets Turnover, Net Profit Margin tidak terjadi multikoliinieritas antara kedua variabel.

\section{Uji Autokorelasi}

Adapun uji yang dapat digunaakan untuk mendeeteksi adanya penyimpeangan asumsi klasik ini adalah uji Durbin Watson (D-W) dengan ketentuan sebagai berikut :

1. $1,7298<\mathrm{DW}<2,2702$ maka tidak ada autokorelasi.

2. DW $<1,894$ atau DW $>2,202$ maka terjadi auto korelasi

Tabel 4. Uji Autokorelasi

\section{Model Summary ${ }^{\text {b }}$}

\begin{tabular}{lrrrrr}
\hline Model & R & $\begin{array}{c}\text { R } \\
\text { Square }\end{array}$ & $\begin{array}{r}\text { Adjusted } \\
\text { R Square }\end{array}$ & $\begin{array}{c}\text { Std. Error of } \\
\text { the Estimate }\end{array}$ & $\begin{array}{l}\text { Durbin- } \\
\text { Watson }\end{array}$ \\
\hline 1 & $.960^{\mathrm{a}}$ & .922 & .911 & .36140 & 1.894 \\
\hline
\end{tabular}

a. Predictors: (Constant), Net Profit Margin, Current Ratio,

Total Assets Turnover, Debt to Equity Ratio

b. Dependent Variable: Pertumbuhan Laba

Sumber : lampiran SPSS, 2018

Berdasarkan hasil olah data diatas maka diketahui bahwa nilai DW adalah sebesar 1,894, nilai Durbin Watson ini terleetak antara 1,7298 - 2,2702, hal ini menunjukkan bahwa dalaam model penelitian ini tidak ada autokoerelasi. Jadi dapat disimpulkan bahwa tidak terdapat autokorelasi dalam model ini karena nilai D-W hiitung berada diantara 1,7298 dan 2,2702 yaitu sebesar 1,894 .

\section{Uji Heteroskedastisitas}

Uji heteroskedastisitas bertujuan menguji apakah dalaam model regresi terjadi ketidaksamaan variance dari residual satu pengamatan ke pengamaatan yang lain. Model regresi yang baik adalah yang tidak terjadi heteroskedastisitas. Pengujiannya gejala heteroskedastisitas daapat dideteksi dengan melihat grafik plot antaara nilai prediksi variabel terikat (ZPRED) dengan resiidualnya (SRESID). Jika titik-titik paada scatter plot tersebut membentuk pola tertentu yaang teraatur (misal bergelombang, melebar kemudian menyempit), maka dapat diindikasikan telaah terjadi heteroskeedastisitas. Hasil pengujian heteroskedasitas pada keetiga perusahaan rokok yang dilaakukan pada peenelitian ini dapat dilihat pada gambar berikut.

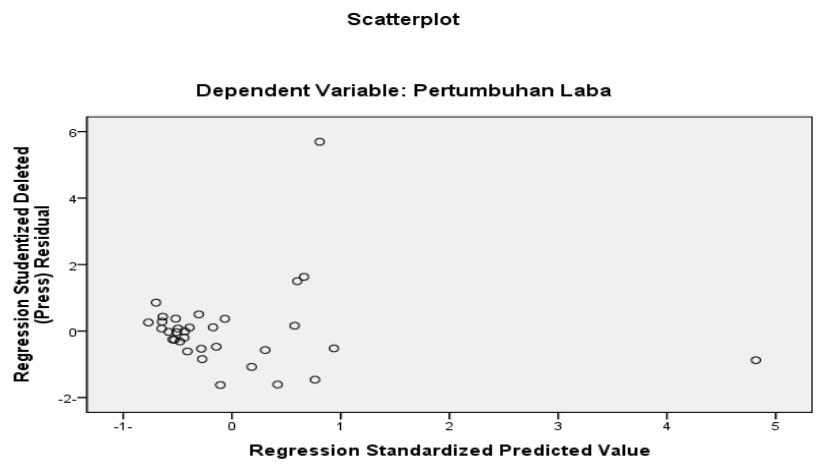

Gambar 2. Uji heteroskedastisitas

Sumber : Lampiran SPSS, 2018

JAD: Jurnal Riset Akuntansi dan Keuangan Dewantara

Vol 2 No 1, Januari-Juni 2019

https://ejournal.stiedewantara.ac.id/index.php/JAD/issue/view/42

Hal $6-10$ 
Berdasarkan scatter plot di atas terlihat bahwa titik-titik menyebar secaraacak serta terseebar di atas maupun di bawah maupun diatas angka 0 pada sumbu Y. hanya. Maka secaara garis besar dapat disimpuulkan bahwa dalam model regresi ini tidak terjaadi heteroskedasitas.

\section{Analisis Regresi Berganda}

Pembuatan persamaan regresi berganda dapat dilakukan dengan menginterpretaasikan angka-angka yang ada di dalam unstandardized coefficient beta. Berdasarkan hasil pengolaahan data dengan menggunakan SPSS maka dapat dilakukan analisis yang akan dijelaskaan seperti dalam tabel 5 :

Tabel 5. Regresi Linier Berganda

\section{Coefficients $^{\text {a }}$}

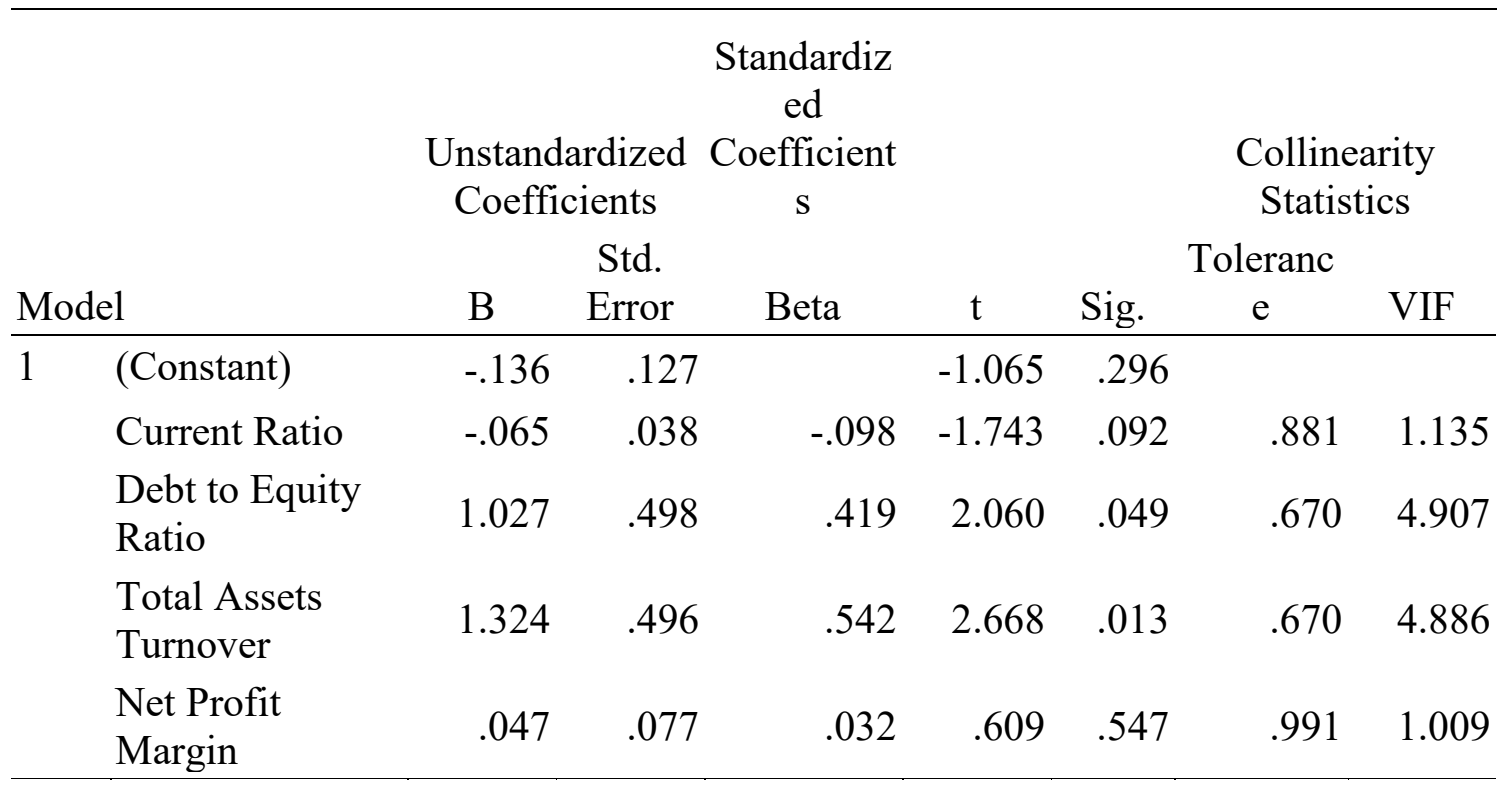

a. Dependent Variable: Pertumbuhan

Laba

Sumber : Lampiran SPSS, 2018

Berikut hasil persamaan regresi berganda berdasarkan data pada tabel di atas :

$$
\mathrm{Y}=-0.136-0.065 \mathrm{X}_{1}+1.027 \mathrm{X}_{2}+1.324 \mathrm{X}_{3}+0.047 \mathrm{X}_{4}+\mathrm{e}
$$

Berdasarkan persamaan regresi di atas maka dapat diinterpretasikan beberapa hal, antara lain:

1. Apabila keempat variabel independen yaitu Current Ratio, Debt to Equity Ratio, Total Asseets Turnover, Net Profit Margin nol atau tidaak mengalami perubahan, maka besarnya peertumbuhan laba adalah -0.136

2. Apabila Current Ratio naik sebesar 1 satuan dan variabel indeependen lain konstan, maka pertumbuhan laba meengalami penurunan sebesar 0,065 .

3. Apabila Debt to Equiity Ratiio naik sebesar 1 satuan dan variiabel independen lain konstan, maka pertumbuhan laaba juga mengalami kenaikan sebesar 1,027.

4. Apabila Total Assets Turnoveer naik sebesar 1 satuan dan variiabel independen lain konstan, maka pertumbuhan laba juga mengalami kenaikan sebesar 1.324.

5. Apabila Net Profit Margin naik sebesar 1 satuan dan variabel indeependen lain konstan, maka pertumbuhan laba juga mengalaami kenaikan sebesar 0.047 .

\section{Pembahasan}

JAD: Jurnal Riset Akuntansi dan Keuangan Dewantara

Vol 2 No 1, Januari-Juni 2019

https://ejournal.stiedewantara.ac.id/index.php/JAD/issue/view/42

Hal 7 - 10 


\section{Pengaruh Current Ratio Terhadap Pertumbuhan Laba}

Hasil uji t menunjukkan bahwa Current Ratio memiliki t hitung sebesar -1.743 dengan $\mathrm{t}$ tabel sebesar 2,048 ( $\mathrm{t}$ hitung $<\mathrm{t}$ tabel) dan nilai signifikansi sebesar $0.092>0.05$ yang artinya Current Ratio tidak berpengaruuh signifikan terhadap pertumbuhan laba karena nilai signifikansi yang diperoleh lebih dari 0.05. Koefisien regreesi variabel sebesar -0.065 , koefisien nilainya negatif artinya terjadi hubungan neegatif antara Current Ratio dengan pertumbuhan laba. Dibuktikan oleh analisis deskriptif menunjukkan apabila hubungan yang negatif atau berkebalikaan antara Current Ratio dengan pertumbuhan laba.

Hasil ini sama dengan hasil peneelitian dari Gunawan dan Wahyuni (2013) yang menggunakan saampel perusahaan perdagangan dimana dinyatakan adaaya menunjukkan bahwa $C R, D A R$ dan $D E R$ tidak berpengaruh signifikan terhadap pertumbuhan laba., namun hal ini berbeda dengan hasil penelitian Mahaputra (2012), yang mana sampel yang digunakan dalam penelitian mereka merupakan manufaktur dimana dinyatakan tidak ada pengaaruh signifikan antara Current Ratio terhadap pertumbuhan laba. Maka peneliti dapat menyimpulkan bahwa tidak ada keseesuaian antara hasil penelitian dengan teori serta peneliitian terdahulu yakni Current Ratio tidak berpengaruh signifikan terhadap pertumbuhan laba.

\section{Pengaruh Debt To Equity Ratio Terhadap Pertumbuhan Laba}

Hasil uji t menunjukkan bahwa Debt to Equity Ratio memiliki t hitung sebesar 2.060 dengan $\mathrm{t}$ tabel sebesar 2,048 ( $\mathrm{t}$ hitung $>\mathrm{t}$ tabel) dan nilai signifikansi sebesar $0.049<0.05$ yang artinya Debt to Equity Ratio berpengaruh signifikan terhaadap pertumbuhan laba karena nilai signifikansi yang diperoleh kurang dari 0.05. Koefisien reegresi sebesar 1.027 yang memiliki nilai positif artinya terjadii hubungan positif antara Debt to Equity Ratio Ratio dengan pertumbuhan laba.

Hasil ini sama dengan hasil penelitian dari Mahaputra (2012), yang mana sampel yang digunakan dalaam penelitian mereka merupakan manufaktur dimana dinyatakan ada pengaruh signifikan antara Current Ratio terhadap pertumbuhan laba, maka peneliti dapat menyimpulkan bahwa ada kesesuaian antara hasil penelitian dengan teori serta penelitian terdahulu yakni Debt to Equity Ratio berpengaruh signifikan teerhadap pertumbuhan laba.

\section{Pengaruh Total Assets Turnover Terhadap Pertumbuhan Laba}

Hasil uji t menunjukkan bahwa Total Asset Turn Over memiliki t hitung sebesar 2.668 dengan $\mathrm{t}$ tabel sebesar 2,048 ( $\mathrm{t}$ hitung $>\mathrm{t}$ tabel) dan nilai signifikansi sebesar $0.013<0.05$ dan dihasilkan koefisien regresi variabel sebesar 1.324 yang artinya Total Asset Turn Over berpengaruh signifikan terhadap pertumbuhuan laba karena nilai signifikansinya lebih kecil dari 0.05 yang artinya Total Asset Turn Over berpengaruh signifikan terhadap pertumbuhan laba.

Hasil ini sama dengan hasil penelitian dari Mahaputra (2012), yang mana sampel yang digunakan dalam penelitian mereka merupakan manufaktur dimana dinyatakan ada pengaruh signifikan antara Total Asset Turn Over terhadap pertumbuhan laba, maka peneliti dapaat menyimpulkan bahwa ada kesesuaian antara hasil penelitian dengan teori serta penelitiian terdahulu yakni Total Asset Turn Over berpengaruh signifikan terhadap pertumbuhan laba.

\section{Pengaruh Net Profit Margin Terhadap Pertumbuhan Laba}

Hasil uji t menunjukkan bahwa Net Profit Margin (NPM) memiliki t hitung sebesar 0.609 dengan $\mathrm{t}$ tabel sebesar 2,048 ( $\mathrm{t}$ hitung $<\mathrm{t}$ tabel) dan nilai signifikansi sebesar $0.547>0.05$ dan dihasilkan koefisien regresi variabel sebesar 0.047 yang artinya Net Profit Margin (NPM) tidak berpengaruh signifikan terhadap pertumbuhan laba karena nilai signifikansinya lebih besar dari 
0.05 yang artinya Net Profit Margin (NPM) tidak berpengaruh signifikan terhadap pertumbuhan laba.

Hasil ini sama dengan hasil penelitian dari Rina Prayuni (2012) yang mengambil saampel pada perusahaan manufaktur Di Bursa Efek Jakarta. Periode 2009-2011 dimana NPM secara parsial tiidak berpengaruh terhadap pertumbuhan laba. Namun hal ini berbeda dengan hasil penelitian Hikmatul Fadillah (2012), yang mana sampel yang digunaakan dalam penelitian mereka merupakan perusahaan manufaktur di BEI Periode 2007-2010 dimana dinyatakan ada peengaruh signifikan antara $N P M$ terhadap pertumbuhan laba. Maka peneliti dapat menyimpulkan bahwa tidak ada keesesuaian antara hasil penelitian dengan teori serta penelitian terdahulu yakni $N P M$ tidak berpengaruh signifikan terhadap pertumbuhan laba.

\section{E. Penutup}

Berdasarkan hasil penelitian yang dilakukan maka dapat ditarik kesimpulan bahwa :

1. Current Ratio tidak berpengaruh signifikan terhaadap pertumbuhan laba pada perusahaan yang bergerak dalam biidang perusahaan sektor property and real estaste yang terdaftar paada Bursa Efek Indonesia (BEI) tahun 2017. Hal ini dibuktikan deengan hasil uji t menunjukkan bahwa Current Ratiio memiliki t hitung sebesar -1.743 dengan t tabel sebesar 2,048 ( $\mathrm{t}$ hitung $<\mathrm{t}$ tabel) dan nilai signifikansi sebesar $0.092>0.05$. Hal ini menunjukkan bahwa kemampuan perusahaan untuk membayar hutang jangka pendek yang akan jatuh tempo dalam waktu satu tahun tidak berdampak pada pertumbuhan laba perusahaan.

2. Debt to Equity Ratio berpengaruh signifikan terhaadap pertumbuhan laba pada perusahaan yang bergeerak dalam bidang perusahaan sektor property and real estaste yanag terdaftar pada Bursa Efek Indonesia (BEI) tahun 2017. Hal ini dibuktikan denegan hasil uji t menunjjukkan bahwa Debt to Equity Ratio memiliki t hitung sebesar 2.060 dengan t tabel sebesar 2,048 (t hitung $>\mathrm{t}$ tabel) dan nilai signifikansi sebesar $0.049<0.05$. Hal ini menunjukkan bahwa efektivitasnya perusahaan menggunakan seluruh asset untuk menghasilkan barang/jasa berkaitan erat dengan seberapa besar/kecil laba perusahaan yang dihasilkan.

3. Total Asset Turn Over berpengaruh signifikan terhadap pertumbuuhan laba pada perusahaan yang bergerak daalam bidang perusahaan sektor property and real estaste yanag terdaftar pada Bursa Efek Indonesia (BEI) tahun 2017. Hal ini dibuktikan dengaan hasil uji t menunjukkan bahwa Total Asset Turn Over memiliki t hitung sebesar 2.668 dengan t tabel sebesar 2,048 ( $\mathrm{t}$ hitung $>\mathrm{t}$ tabel) dan nilai signiifikansi sebesar $0.013<0.05$. Hal ini menunjukkan bahwa efektivitasnya perusahaan menggunakan seluruh asset untuk menghasilkan barang/jasa berkaitan dengan seberapa besar/kecil laba perusahaan yang dihasilkan.

4. Net Profit Margin (NPM) tidak berpengaruh yang signifikan terhadap pertumbuhan laaba pada perusahaan yang bergeraak dalam bidang perusahaan sektor property and real estaste yang terdaftar pada Bursaa Efek Indonesia (BEI) tahun 2017. Hal ini dibuktikan dengan hasail uji t menunjukkan bahwa Net Profit Margin (NPM) memiliki t hitung sebesar 0.609 dengan $t$ tabel sebesar 2,048 ( $\mathrm{t}$ hitung $<\mathrm{t}$ tabel) dan niilai signifikansi sebesar 0.547>0.05. Hal ini menunjukkan bahwa nilai laba bersih tidak berdampak kepada nilai Net Profit Margin (NPM). 


\section{DAFTAR PUSTAKA}

Fahmi, Irham. 2012. Analisis Laporan Keuangan. Bandung: Badan Penerbit Alfabeta, Bandung.

Gunawan, A., \& Wahyuni, S.F. 2013. Pengaruh Rasio Keuangan Terhadap Pertumbuhan Laba pada Perusahaan Perdagangan di Indonesia. Jurnal Manajemen \& Bisnis, 13(1):63-84.

Ghozali, I. 2011. Analisis Multivariate Dengan Program SPSS. Edisi Kelima. Badan Penerbit Universitas Diponegoro, Semarang.

Harahap, Sofyan Syafri. 2010. Analisis Kritis atas Laporan Keuangan. Jakarta: Raja Grafindo Persada.

Kasmir. 2012. Analisis Laporan Keuangan. Penerbit PT. Raja Grafindo Persada. Jakarta.

Kasmir. 2015. Analisis Laporan Keuangan. Edisi Pertama. Cetakan ketiga. PT. Raja Grafindo Persada, Jakarta

Prayuni, Rina. 2012. Pengaruh Current Ratio, Debt to Equity Ratio, Net Profit Margin dan Total Asset Turn Over Terhadap Pertumbuhan Laba pada Perusahaan Manufaktur yang Terdaftar di Bursa Efek Indonesia Tahun 2009-2011. Jurnal Ekonomi.

Mahaputra, I.N.K.A. 2012. Pengaruh Rasio-Rasio Keuangan Terhadap Pertumbuhan Laba Pada Perusahaan Manufaktur Yang Terdaftar Di BEI. Jurnal Akuntansi \& Bisnis 7(2).

Utomo, L. P. (2018). Kecurangan Dalam Laporan Keuangan "Menguji Teori Fraud

Triangle". Jurnal Akuntansi dan Pajak, 19(1), 77-88.

Sugiyono. 2011. Metode Penelitian Kuantitatif, Kualitatif dan R\&D. Bandung: Alfabeta Sugiyono. 2016. Metode Penelitian Kuantitatif, Kualitatif dan R\&D. Bandung: Alfabeta 